\title{
Actualizing hope and joy in K-12 Curricula through Daisaku Ikeda's human education
}

\author{
Nai-Cheng Kuo, Amy Wood, \& Kyra Williams
}

Department of Teaching and Leading, Augusta University, Augusta, Georgia, USA ${ }^{1,2,3}$ nkuo@augusta.edu ${ }^{1 *}$,amywood@augusta.edu ${ }^{2}$, kyrwilliams@augusta.edu ${ }^{3}$

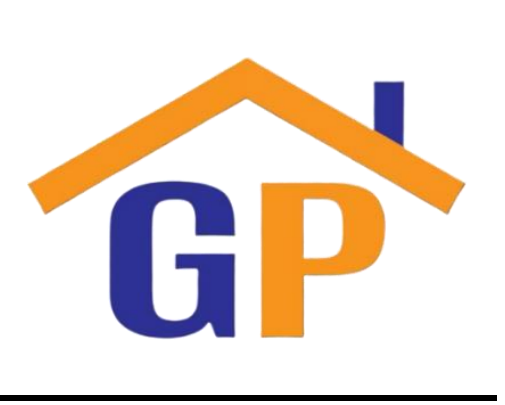

Article History

Received on 3 August 2021

$1^{\text {st }}$ Revision on 9 September 2021

$2^{\text {nd }}$ Revision on 24 September 2021

Accepted on 16 September 2021

\begin{abstract}
Purpose: Our study aims to create a framework grounded in Daisaku Ikeda's philosophy of education for educators and researchers to implement and evaluate human education in the classroom.
\end{abstract}

Research Methodology: We first synthesized the eighteen chapters by scholars involved in Ikeda studies, published in the book entitled: Hope and Joy in Education: Engaging Daisaku Ikeda across Curriculum and Context to discover the main themes in Ikeda's human education. Based on these themes, we selected six children's stories developed by Ikeda to design lessons. We then conducted surveys with ten K-12 teachers across disciplines and school districts to explore their perspectives toward humanity and their feedback on our lesson design.

Results: Our finding indicates that creating hope and joy in education is inseparable from human revolution, value creation, happiness, the greater self, global citizens, as well as life and death. In addition, the participant's responses to the survey questions help educators and researchers understand what K-12 teachers look for in order to implement lessons on humanity more efficiently and effectively.

Limitations: By no means would we consider our lesson design exemplary or applicable in all different contexts. Instead, we consider these lessons a starting point to continue exploring a better way to teach humanity in school.

Contribution: Seeing examples of lesson plans on humanity and learning from K-12 teachers' perspectives provide an aspect for educators and researchers to use, extend, or expand the present study to bring hope and joy to students in their local contexts.

Keywords: Humanity, K-12 Curricula, Human education, Daisaku Ikeda

How to cite: Kuo, Nai-Cheng., Wood, A., \& Williams, K. (2021). Actualizing hope and joy in K-12 Curricula through Daisaku Ikeda's human education. Journal of Social, Humanity, and Education, 2(1), 19-34.

\section{Introduction}

Daisaku Ikeda (1928) is a Japanese philosopher, educator, and prolific writer. He emphasizes that education is to help students develop genuine character, embrace challenges, and bring forth their full potential. His philosophy of human education has profoundly impacted society, humanity, and education (Kuo, 2020) and has been researched and applied in K-12 and higher education. Inspired by the book Hope and Joy in Education: Engaging Daisaku Ikeda across Curriculum and Context, edited by Isabel Nunez and Jason Goulah (2021), we ask ourselves: how we, as teachers, can also bring hope and joy to the students in our local schools. In Phase One, we reviewed and synthesized the eighteen chapters of the book contributed by scholars involved in Ikeda studies to discover themes around hope and joy in education. In Phase Two, based on the themes, we selected six children's stories created by Ikeda to design lessons. In Phase Three, we conducted surveys with ten K-12 teachers across 
disciplines and school districts to explore their perspectives toward humanity and their feedback on our lesson design.

\section{Phase One: Review and Synthesis}

In Phase One, we utilized qualitative text analysis (Kuckartz, 2013) to review and synthesize the eighteen chapters of the book Joy and Hope in Education. We described each of the themes in the following.

\section{Human Revolution}

Traditionally, humanism is viewed as using encouragement to replace authority and corporal punishment or simply treating others nicely. However, Ikeda's perspective toward humanism is to restore the spirit of self-reliance, self-discipline, and self-improvement (Ikeda, 2010a). All of these require a human revolution, a process of individual inner transformation. Ikeda believes that a single person's change in behavior will impact his or her environment and eventually the destiny of society as a whole. He argues that "being born human does not make one a human being." We must "make a tenacious effort to live as human beings." (Ikeda, 2002, p. 139). Through this never-ending, continual process of human revolution, we gradually live to the most expansive life condition, moving from the egocentric lesser self to the compassionate greater self (Ikeda, 2010a).

Inukai and Okaura (2021) argue that teachers' human revolution is the first step of implementing human education in the classroom. They state: "if the flower does not grow or bloom, it is not because it was a 'bad' seed, but the grower was unable to attend to the needs of that seed (p. 13). Rather than blaming students and environmental factors, teachers need to first reflect on their relationships with their students, treasure students, and improve the quality of their teaching. As Ikeda (2017) says: "the fact that one cannot see the supreme jewel in another means that one cannot recognize it in oneself" (p. 80). Thus, if teachers only see what their students cannot do, at the same time, they have denied the supreme jewel that exists within themselves and their students (Hall et al., 2021). Jason Goulah, the foremost pioneer scholar in Ikeda Studies, summarizes the fundamental meaning of Ikeda's human education as follows:

Human education is twofold. On one hand, it is an approach that calls on us to encourage the individual right in front of us, to believe in everyone's unique and unlimited potential, to never give up on anyone, no matter what. But it is also, equally, an approach that demands that we awaken to the full scope and possibility of our own humanity and humanness. For Ikeda, being human is an action, a continual process of being and becoming more 'fully human' where education (kyoiku; 教育) is the mutual growth (kyoiku; 共育) of oneself and others...Ikeda (1991-2011) calls this process of becoming “ningen kakumei” (人間革命), or "human revolution.” More specifically, human revolution is a volitional and continual transformation within the deep interiority of one's life itself. It moves us from what Ikea...calls the egocentric 'lesser self' (shoga; 小我) to the infinite or 'greater self' (taiga; 大我) that is one with the universe and attuned to the ways our thoughts and actions interweave with the larger web of causality across time and space...To enact such transformative human education, Ikeda advocates for the following four interlocking commitments and ideals: dialogue, global citizenship, value creation, and creative coexistence (Goulah, 2021, pp. xvii-xviii).

Goulah (2021) states that the human revolution is Ikeda's most important and enduring contribution to humanity. Although there are different terms to describe education on humanism, such as humanistic education and humane approaches, Goulah explains that "human education" is the one that truly conveys Ikeda's profound thinking in his original Japanese version. Linguistically, human (related to man's nature), humane and humanitarian (kindness and benevolence), and humanistic (anthropocentric) all possess different meanings (Lifshitz, 1997). Thus, it is necessary to use the adequate term, human education, when referring to Ikeda's philosophy of education. 


\section{Value Creation}

Another idea of Ikeda's that goes hand in hand with the human revolution is value creation. Ikeda (2010b) says that true happiness can only be found in a life of value creation, which is "the capacity to find meaning, to enhance one's own existence and contribute to the well-being of others, under any circumstance" (p. 112). He describes the importance of value creation from three aspects: 1) "value creation that always takes hope as its starting point;" 2) "value creation of people working together to resolve issues;" and 3) "value creation that calls forth the best in each of us" (Ikeda 2014, p. 2). In other words, a life of value creation gives people hope, encourages them to work collaboratively, and awaken to their best potential. To create value, Lupinacci (2021) reminds us of two concepts: centric thinking and value-hierarchized dualisms. Centric thinking is "our culturally-rooted assumptions that position certain individuals, social roles, and material conditions as superior" (p. 161). He goes on to explain centric thinking and its relation to value-hierarchized dualisms stating that

Centric thinking results in culturally specific sets of value-hierarchized dualisms that engender false, unjust, and unsustainable actions and understandings of rationality...Examples include the dualisms that underpin anthropocentrism (human/non human), racism (white/not white), classism (wealthy/not wealthy), sexism (male/not male), ableism (able-bodied/not able-bodied), and so on. (Lupinacci, 2021, p. 161).

There are alternatives to the dualisms. Ikeda (2014) advocates that we "create new meaning or value from a different perspective on dualistic thinking" (Lupinacci, 2021, p. 162). These dualisms inform how we think and act, but that does not necessarily mean they must hold the same meaning they once did. To create value and reach our greater selves, we must rewire our thinking about dualisms to achieve creative coexistence.

\section{Happiness}

Ikeda (2010b) argues that happiness must be the ultimate goal of education. He says, "educators earnestly seeking their students' happiness will naturally come to treat them with unconditional trust and warm respect." He continues to say, "one of the great problems in modern education...lies in its tendency to lose sight of student's happiness as its fundamental purpose" (p. xi). From Ikeda's perspective, happiness is not the absence of problems. Rather, "it is the courage, appreciation, hope, and joy born from realizing one's unlimited capacity to create meaning from both learning and life's realities, meaning that contributes to the betterment of oneself and others and, thereby, to positively transforming society" (Goulah, 2021, p. xv). Throughout his youth, Ikeda suffered from weak health, aggressive nationalism, wars, and the loss of her brothers, which all lead him to understand the importance of happiness. Berry (2021), a scholar on critical race feminism in the context of curriculum studies, states that "engaging with Ikeda's work, I realized that his notions of happiness, pain and hope are deeply rooted in his experiences. As such, it is clear that his experiential knowledge formed a curriculum of joy." (p. 82). Pain can fuel one's heart to explore the meaning of happiness as long as the person does not lose hope.

Hope allows people to imagine the future no matter how challenging their circumstances are. It is the driving force that makes people keep moving forward. Hope may be given from outside, but ultimately the lasting hope could only come from within. Hope generates courage, and courage generates action for one to find ways to break the deadlock, transform the situation, and finally realize one's meaning of existence. When one could find the meaning of existence and lead a contributive life, it is genuine happiness (Ikeda, 2017). Hope, as defined by Ikeda, "is a flame that we nurture within our hearts," and it "must be fanned and kept burning through our own determination" (Ikeda, 2017, p. 5). In his book, hope is a Decision, Ikeda (2017) states: "hope is the force that enables us to take action to make our dreams come true... When we possess the treasure of hope, we can draw forth our inner potential and strength. A person of hope can always advance" (p. 5). He continues to say, "There may be times when confronted by cruel reality, we verge on losing all hope. If we cannot feel hope, it is time to create some. We can do this by digging deeper within, searching for even a small glimmer of light, for the possibility of a way to begin to break through the impasse before us" (p.6). 
One way to help our students find hope is to give them courage and encourage them to look at the positive side. As teachers, we also need to do the same when facing challenges regardless of political, ethical, professional, or personal issues. As Mattheis (2021), a former K-12 principal, states:

I found myself stuck in the contradictory space in which many critically conscious teachers find themselves: I want radical change on behalf of children who deserve a better world; but I also recognize that physically being in a community with the tens of millions of children in the United States, who spend so many hours of so many days of their lives in schools, requires us to joyfully be in these spaces even as we critique them. (p. 46)

Mattheis (2021) argues that the solution to confront a political battle is to respect the dignity of each person, affirm the differences between people, and connect to people. Doing these is likely to lead to person-to-person dialogue. She states, "regardless of the system of governance in place, human-level connections should guide ethical decision making" (p. 49). The human-level connections are also crucial in the classroom to build a good relationship with students. If teachers are willing to learn from their students, and students know that they can teach their teachers, teaching, and learning become reciprocal. Hope is "an action to refuse passivity and to recognize that we have it within our human capacities to remedy the current trajectory that industrial human thought and behavior have us on" (Lupinacci, 2021, p. 159).

When current education is centered on standardized assessments, Ikeda reminds us that education is more than transmitting knowledge but treasuring each student's uniqueness and unlimited potential. Our students need to know that we, as their teachers, believe in them. When we touch students' hearts and help them develop character and social-emotional skills, they can better their personal lives and society as a whole. Donahue-Keegan (2021) considers that Ikeda's philosophy of education is aligned with social and emotional learning for K-12 students.

\section{The Greater Self}

Grounded in Ikeda's work, Bogen (2021) says that understanding and cultivating the greater self is a lifelong journey that requires creating cultures of peace and having a heart open to hope and joy. Learning to know and respect ourselves is how we reach our greater self, leading to connection and concern with others. To achieve the greater self, it must start from the change in oneself. Bogen quotes:

An appreciation of human life as inherently diverse and mutable; embodies an unwavering faith in the limitless potential and dignity of all people. I am confident that such a perspective offers a path toward peace and harmonious coexistence, embracing all forms of ideological, religious, philosophical differences. (Ikeda, 2018, p. $x$ )

It is important to focus on positivity throughout the process of reaching the greater self. In response to Ikeda's belief of not negating the less noble aspects of ourselves, Bogen (2021) expresses that "processes built on affirmation are so much more joyful than those built on negation, which often gets dragged down by a solemn sense of obligation" (p. 147). As Ikeda (2010a) stated in a university address at the University of California, Los Angeles in 1974:

To live for the greater self does not mean abandoning the lesser self, for the lesser self is able to act only because of the existence of the greater self. The effect of that relationship is to motivate the desires and attachments common to all human beings to stimulate the advancement of civilization. (p. 140)

To reach the greater self, it is essential to view our current selves and previous selves positively. Our greatest selves are made up of each aspect of who we are. To view certain aspects negatively would be to view ourselves negatively, which prevents us from achieving growth towards our best self. As 
teachers, we should always nurture the goodness inside each student. Ikeda believes that to nurture the good, dialogue is the most effective tool as a means for peacebuilding (Bogen, 2021). When we desire to engage in dialogue for building peace, we can break the cycle of consciously or unconsciously categorizing people into simplistic binaries, such as "good or bad" and "friend or foe" (Bogen, 2021, p. 148). Dialogue is a commitment for mutual growth, which Bogen considers transformative dialogue to be essentially educational in nature. Bogen (2021) considers dialogue to be "both a stance that upholds the possibility of connecting with others, with all parties changing for better and a process designed to make that happen" (p. 149). The key to achieving such dialogue, according to Ikeda (2009),

Is devoting our very lives to listening and learning from those different from us. This humble willingness to learn is profoundly meaningful, invariably fostering deep, empathetic connections. Not only does this resonance enable us to understand others on a deeper level, but it also acts as a mighty impetus for our true self -our greater self to flower within us.

To achieve the greater self, we need to have an open mind and a humble willingness to learn. It is vital to keep the flame of concern for the well-being of others alive in our hearts and remember that "if we keep in mind that everyone suffers, we can communicate with anyone (Bradford, 2018)" quoted by Bogen (2021, p. 153). Remaining hopeful and joyful in everything we do is the most important step in understanding and becoming the greater self.

\section{Global Citizens}

In his peace proposal to the United Nations, Ikeda (2021) stresses that building global society and cultivating humanity in each person's life are fundamental solutions to overcome complex crises such as a pandemic, discrimination, and human rights. He describes three qualities of being a global citizen: 1) "the wisdom to perceive the interconnectedness of all life and living," 2) "the courage not to fear or deny difference, but to respect and strive to understand people of different cultures and to grow from encounters with them," and 3) "the compassion to maintain an imaginative empathy that reaches beyond one's immediate surroundings and extends to those suffering in distant places (Ikeda, 2010b, pp. 112-113)." Teachers should determine that both themselves and their students will advance together to cultivate the three qualities of global citizens within them. Through this effort, they tackle problems in their local and global communities with needed wisdom, courage, and compassion, and finally live as fully human beings.

Huckaby (2021) states that if education is to create value, help students become happy, and right the wrongs of our civilization, it is crucial to awaken the mission of each individual. Through collective efforts, justice will prevail. To achieve this, Ikeda calls for fostering global citizens "who possess both a positive philosophy and true capability, and who are dedicated to joining hands with all people on this planet and advancing with them" (World Tribune, 2001, p. 7). Dialogue can break vicious cycles and create a genuine coexistence. Bradford (2021) states that Ikeda's philosophy and practice of dialogue help us "reframe our challenges as opportunities to grow and make meaning, learning how to create value for ourselves and our communities regardless of the difficulties of our circumstances" (p. 63). In addition, reading good literature and having a poetic spirit also allow people to broaden themselves, generate dialogue, and transcend time, the borders of the world, and differences in culture. Patterson (2021) states that classroom discussions create a dialogue forum for students to share different, sometimes conflicting, perspectives. These experiences help them think more deeply about their role as global citizens and brainstorm creative and peaceful coexistence.

\section{Life and Death}

"Death is more than the absence of life; that death, together with active life, is necessary for the formation of a larger, more essential, whole" (Ikeda, 2010a, p. 167). In other words, "life and death are two phases of a continuum. Life does not begin at birth nor end at death" (SGI Quarterly, 2015). As Goulah quotes: 
We are born in this world to enjoy life. We are not born to suffer. This is the basic premise of the Lotus Sutra on the nature of human existence. To live happily and at ease in the world means to enjoy our work and family life, to enjoy helping others...If we have a truly high state of life, then even when unpleasant things happen, we view them as making life all the more interesting, just as a pinch of salt can actually improve the flavor of a sweet dish. We feel true delight in life, whatever happens.

(Ikeda, 1997, p. 8).

As a teacher educator, Goulah shares these teachings with his students. He states that "hope here is not passive, wishful thinking; it is determined and engaged, changing everything, starting with our lives (Ikeda, 2017, p. 5)". Another statement Goulah makes about his shared beliefs with Ikeda is:

Ikeda entreats us to summon forth boundless hope from the depths of our lives, to charge into our own human revolution by relieving others' suffering in their moments of deep despair, pain, and unhappiness-and, not least, by imparting joy. This is our task as educators, for "the ultimate tragedy in life is not physical death. Rather, it is the spiritual death of losing hope, giving up on our own possibilities for growth" (Ikeda, 2017, p. 6).

Fundamentally, we all need to "first of all learn about death, and then about other things" (The Gosho Translation Committee, 2006). Through understanding death, we treasure every moment, create value, and respect the dignity of our lives and others'.

In summary, our synthesis of the book Hope and Joy in Education indicates that to actualize hope and joy in K-12 curricula, teachers could start from central themes like human revolution, value creation, happiness, the greater self, global citizens, as well as life and death. Figure 1 shows a literature map of our synthesis and how we later used it for our lesson design in Phase Two.

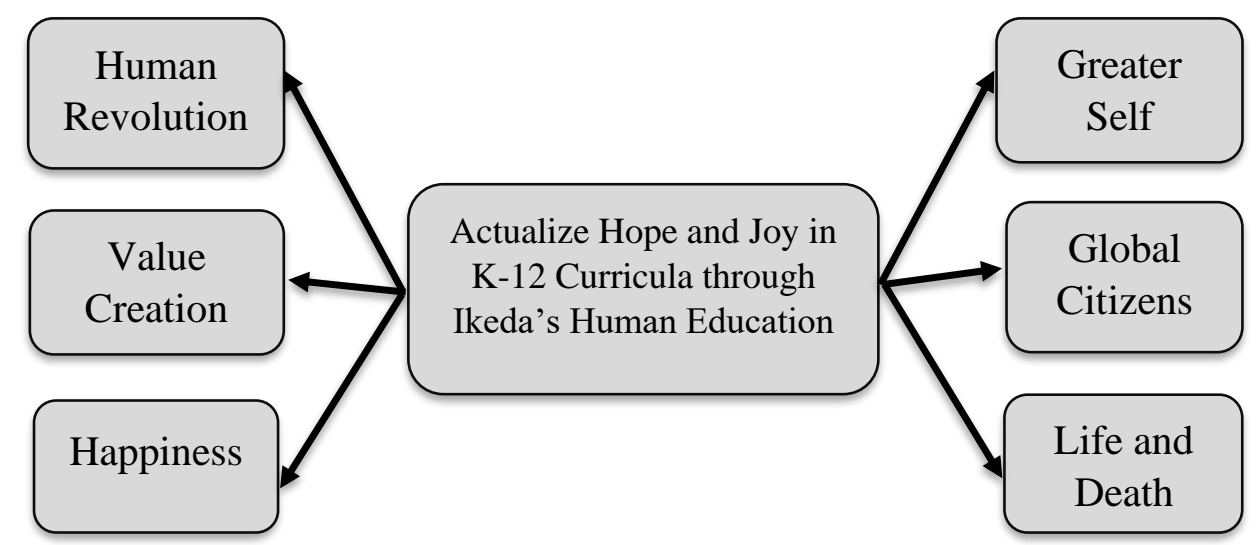

Figure 1. Themes for actualizing hope and joy in K-12 curricula

\section{Phase Two: Identify Videos and Create Lessons}

In Phase Two, we identify children's stories created by Ikeda to develop lesson plans. Ikeda's children's stories have both print and video versions. The videos are free and accessible at https://www.youtube.com/channel/UCm6DTgN7mV07jumHkVGgsDA. The length of each videobased Ikeda's children's stories is approximately 30 minutes. Ikeda states that he wrote these stories "with the hope of imparting courage and hope to children, and thus contributing in some way to planting' seeds of the heart' that teach the importance of cherishing friendship and trust" (Ikeda, n.d.).

We adopt the backward design process (Childre et al., 2006) to create the lessons. The backward design was originally created by Grant Wiggins and Jay McTighe (1998), which consists of three 
stages: 1) identify desired results, 2) determine acceptable evidence, and 3) plan learning experiences and instruction. Expanding the stages, each of our lessons has five components: 1) an overview of the lesson, 2) curriculum standards, 3) observable and measurable learning objectives, 4) assessments, and 5) active learning and instructional activities. We selected six of Ikeda's videos based on the themes of our synthesis. The complete lesson plans can be downloaded at https://sites.google.com/view/allabouthumanity/home. In the following, we briefly introduce Ikeda's videos and our lesson design.

\section{Lesson 1. Hope (The Cherry Tree)}

After a war destroyed Taichi's village and killed his father, Taichi finds hope by nurturing a cherry tree in a harsh winter. With help from an older man, Taichi sees the tree blossom into a new life. This lesson teaches students the importance of finding hope within themselves and helping others do the same. Students will have the opportunity to delve into the deeper meaning of hope and apply it in the real world with this engaging lesson. Cultural diversity is embedded in the lesson content, allowing students from different cultures to see their shared humanity.

\section{Lesson 2. Happiness (The Princess and the Moon)}

Sashiko is an ill-tempered and unhappy little girl. She is taken on a mystical moonlit journey by a rabbit that changes her view of the world by showing how pleasant and happy people can be. On the moon, Sachiko sees, deep in her heart, that she wants to be happy, so is everyone around her. We are all truly princes and princesses, even if we cannot always see it. The Princess and the Moon takes the main character on a journey where she learns to look into her own heart and the hearts of others and see them for who they can be. This lesson introduces the concept of reflection to children as they think about happiness. The message of inner beauty helps children see their value and worth.

\section{Lesson 3. Friendship (The Princess of the Desert Kingdom)}

The Princess of the Desert Kingdom is determined to save her country and people during a drought. She and her animal friends face many challenges in their journey to find water in a desert. Their friendship leads them to save lives and change the destiny of their country through restoring and reviving people's humanity. This lesson teaches students how beautiful and powerful a genuine friendship can be. When facing challenges, we may all feel scared and want to retreat. However, when good friends and encouragement surround us, our hearts will be instilled with hope and courage. This lesson also teaches students the impacts of human beings' behavior on their living environment.

\section{Lesson 4. Sportsmanship (The Winds of Victory)}

Kenji, a new student at Yuta's school, joins the soccer team. Kenji injures Yuta during the first game he plays, and despite being unable to play because of his ankle injury, Yuta's team spirit remains the same. Yuta teaches Kenji the meanings of fair play and sportsmanship as he takes pride in cleaning the team's equipment before games and changes his negative situation into a positive one. This lesson teaches students how to win and lose gracefully. Students will also learn why it is important to view others who differ as humans and treat everyone equally. When students treat each other with respect and equality and let go of any resentment toward others, the spirit of peace emerges, and through that peace, everyone can emerge victoriously.

\section{Lesson 5. The Power of the Heart (Rainbow Mountain)}

Three young friends set out to reach the top of Rainbow Mountain by hiking on foot but are stopped by many obstacles along the way. By working together and never giving up, they reach their goal and celebrate their success at the top of the mountain. This lesson teaches students that there is no mountain that cannot be climbed when they put their heart into it. It teaches the importance of never giving up and always completing things you set out to achieve. This lesson will teach students that they can do anything they set their mind to if they put their heart into it and never give up.

\section{Lesson 6. Courage (The Snow Country Prince, Parts 1-3)}

The Snow Country Prince is about a young boy and his sister in a snow country's fishing village. The harsh winter season marks the departure of the children's fisherman father, who had to travel to find 
work, and the swans' arrival. The Snow Country Prince asks Goichi, a frail and meek boy, to look after the swans in the frigid, harsh elements. Goichi and his young sister take the responsibility of caring for the swans to heart and learn a wonderful lesson. The Snow Prince mentors Goichi and helps him understand that it takes courage to handle a big responsibility. The three parts of the lesson with three videos teach students how to fill their hearts with a powerful wish for someone's happiness and grow as great individuals full of courage and compassion. Children's pure and beautiful humanity will awaken the heart of others and create a beloved community.

Table 1 shows how the six themes identified in the synthesis are corrected with Ikeda's videos and our lesson design. The lessons cover most of the main themes identified in our synthesis. Two of the videos (i.e., The Cherry Tree and The Snow Country Prince) particularly include storylines about children experiencing life and death in their childhood.

Table 1 . The synthesis of the themes and the lesson plans

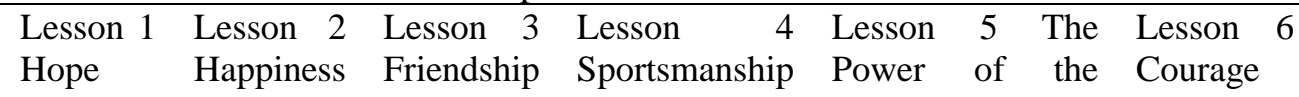
Heart

\begin{tabular}{|c|c|c|c|c|c|c|}
\hline & & & & & \\
\hline $\begin{array}{l}\text { Human } \\
\text { revolution }\end{array}$ & $*$ & $*$ & $*$ & $*$ & $*$ & $*$ \\
\hline Value Creation & $*$ & $*$ & $*$ & $*$ & $*$ & $*$ \\
\hline Happiness & $*$ & $*$ & $*$ & $*$ & $*$ & $*$ \\
\hline The Greater self & $*$ & $*$ & $*$ & $*$ & $*$ & $*$ \\
\hline Global Citizens & $*$ & $*$ & $*$ & $*$ & $*$ & $*$ \\
\hline Life and Death & $*$ & & & & & $*$ \\
\hline
\end{tabular}

\section{Phase Three: Teacher Survey}

In Phase Three, we explored K-12 teachers' perspectives toward humanity and their feedback on our lesson design. We aimed to recruit a sample of ten teachers across disciplines and school districts in our local public schools. After obtaining IRB approval, we sent invitation emails to teachers in the Central Savannah River Area (CSRA). The teachers who participated in our project were all voluntary. The survey questions we asked them included: 1) Could you describe your teaching experiences? 2) What do you view in your role as a teacher? 3) Do you think it is possible to foster students' humanity in the traditional curriculum? Please explain. 4) What do you like most about our lesson design? 5) What may be teachers' biggest fear or concern about adopting or modifying our lesson plans to foster students' humanity? 6) What information is missing or would make it possible for teachers to adopt or modify our lesson plans for their students? The survey results are addressed in the following. All participants' names are pseudonymous.

\section{Participants' Teaching Experiences}

Beth has been working in public schools for eighteen years. She taught middle-grade mathematics and social studies for ten years and has been a middle school librarian for eight years. Bianca is an elementary education teacher. She has been teaching for seven years and has taught pre-kindergarten, $2^{\text {nd }}$, and $3^{\text {rd }}$ grades. Currently, she works at a Title I school and has taught all subjects, mainly reading and mathematics. Erin works as a secondary English teacher for three years. Before that, she worked as a substitute in the special education classroom for one year. She also worked with adults with disabilities and taught development courses to staff. Grace has been teaching for nine years. She began her career by teaching Spanish in K-5. Then, she taught all subjects in the $1^{\text {st }}$ grade for seven years and is currently teaching $3^{\text {rd }}$ graders. Katniss has been teaching elementary students for thirteen years within two counties in Georgia. She has taught in Title I schools with experience in K-5. She taught giftedness and special education programs. She currently teaches early intervention programs for students in the $3^{\text {rd }}$ and $5^{\text {th }}$ grades. Kelsie has been teaching for nineteen years across four different schools. She has primarily taught $3^{\text {rd }}$-grade students and is currently a $5^{\text {th }}$-grade teacher. Patrice is certified in elementary and special education. She taught in elementary schools in the Philippines for 
nineteen years before working in the U.S. in 2018. She is currently a public high school special education teacher in South Carolina. Rachel has been teaching for seven years. She has taught $6^{\text {th }}$ and $7^{\text {th }}$-grade mathematics and science in Georgia and has experience teaching in Title I schools. Tina has been an educator for twelve years. She spent four years teaching interrelated high school special education, eight years teaching middle-grade English language arts and mathematics, and two years as an interrelated middle-grade teacher. Wanda has been teaching at a Title I school for twenty-seven years. She has taught all subjects, but mainly mathematics and science. She has spent element years teaching $5^{\text {th }}$ grade, one year teaching $1^{\text {st }}$ grade, two years teaching $4^{\text {th }}$ grade, and thirteen years in $3^{\text {rd }}$ grade. She has been teaching early intervention programs and enrichment programs in reading and mathematics.

Table 2. A summary of participants' teaching experiences

\begin{tabular}{|c|c|c|c|}
\hline & Year of Teaching & Grade Level & Subject Matters \\
\hline Beth & 18 years & Middle School & Math, Social Studies \\
\hline Bianca & 7 years & Elementary School/Title 1 & All Subjects \\
\hline Erin & 3 years & High School & Special Education \\
\hline Grace & 9 years & Elementary & Spanish and ELA \\
\hline Katniss & 13 years & Elementary School & Gifted and Special Education \\
\hline Kelsie & 19 years & Elementary & All Subjects \\
\hline Patrice & 21 years & $\begin{array}{l}\text { Elementary and High } \\
\text { Schools }\end{array}$ & Special Education \\
\hline Rachel & 7 years & Middle School/Title 1 & Math, Science \\
\hline Tina & 12 years & Middle and High Schools & Special Education, Math, ELA \\
\hline Wanda & 27 years & Elementary School & Special Education, Early Intervention \\
\hline
\end{tabular}

Table 2 above summarizes participants' years of teaching, grade levels, and subject matters they teach, indicating that participants have various teaching experiences.

\section{Participants' View of Their Role}

Beth says that for students to become functioning adults, teachers need to focus on the whole child. Bianca expresses that her role as a teacher is to help students grow and develop. That means she sometimes needs to play as a mother, teacher, nurse, and disciplinarian. She emphasizes the importance of teaching students social cues, especially in elementary school, which is often the first time students interact with others outside their home setting. She states that teachers must be sensitive to students' diverse cultural backgrounds and adjust instruction accordingly. Erin views herself as a facilitator, helping students develop critical thinking skills and encouraging them to never stop learning. She is eager to give all knowledge she has to her students. Grace views herself as a teacherleader, a go-getter. She seeks to lead by example and to inspire her colleagues and students. She wants to help students develop academic abilities, living skills, and critical thinking to change society positively. Katniss views herself as interventionist. She has a goal of helping boost her students' confidence and ability to read. She seeks to help her students find a love for reading and being confident in pursuing their full potential. Kelsie views herself as more than just someone who teaches standards. She believes that teachers should be role models for their students. They also need to play multiple roles, such as nurses and counselors, to help students become successful and independent citizens. Patrice believes that teachers need to be lifelong learners. Through learning about new knowledge and growing with students, she sees students not making adequate progress as an opportunity for her to continue exploring ways to assist her students in learning. She wants to help her students develop the quality of global citizens and become contributing members of society. Rachel states her role is to build relationships with students. She wants to let students know that she cares about them and supports them. She wants them to learn the content that she teaches, but more importantly, she wants them to learn that they have someone rooting for them. Tina believes that her role as a teacher is to create caring, thoughtful, thinking individuals. Wanda views herself as an inspiration to her students. She states that she seeks to inspire her students to enjoy learning and become responsible citizens who can help make our world a better place. She views her role as 
helping students become successful in their chosen fields. She wants to instill characteristics in them that will lead them to become respectful and responsible people.

Table 3. A summary of what participants view their roles as teachers

\begin{tabular}{lll}
$\begin{array}{l}\text { Academic } \\
(\text { e.g., content areas) }\end{array}$ & $\begin{array}{l}\text { Social/Emotional/Behavioral } \\
\text { (e.g. life skills) }\end{array}$ & $\begin{array}{l}\text { Moral } \\
\text { (e.g. caring, responsible } \\
\text { citizens) }\end{array}$ \\
\hline$*$ & $*$ & $*$ \\
$*$ & $*$ & $*$ \\
$*$ & $*$ & $*$ \\
$*$ & $*$ & $*$ \\
$*$ & $*$ & $*$ \\
$*$ & $*$ & $*$ \\
$*$ & $*$ & $*$ \\
$*$ & $*$ & $*$ \\
\hline$*$ & $*$ & $*$
\end{tabular}

Table 3 above indicates that most participants view their roles across academic, social/emotional/behavioral, and moral support to their students.

\section{Possibilities of Fostering Students' Humanity in the Traditional Curriculum}

Beth says that concrete examples of character and humanity tied with the learning objects give students touchpoints for emotional interactions. Many students do not have such touchpoints in their home lives. Thus, a structured display of these examples of humanity, like those found in the lessons, is necessary. Bianca believes that a balance must exist between the textbook curriculum and the texts that support students' social-emotional health. She suggests that sometimes the best examples of ways to demonstrate an idea are not found in a textbook but rather a real-life scenario or a book other than textbooks. Erin shares that there are innumerable life lessons that can be taught right alongside academics. Humanity can be fostered through any curriculum if teachers are willing to find opportunities. Grace says it is possible to foster students' humanity in the curriculum by supporting a growth mindset. Because students learn from observing others and are not always taught at home how to be good human beings, she states that teachers must take a stand and teach the positive side of humanity if they want any negative cycle to end. She believes when teachers support and teach a growth mindset, students are likely to develop into good citizens. Katniss believes that a more modern curriculum allows for teaching the outside world to students. However, it is up to teachers' willingness to incorporate materials into their classroom and lessons to foster humanity. She also suggests that students are more receptive when given the opportunity to see how the idea can be applied. Kelsie comments that teachers could foster students' humanity within K-12 curricula, but it takes extra time and effort for preparation and implementation. Patrice shares that humanity had always been emphasized in her teacher education program since the 1980s. Born during the Cold War (1947-1991), she realizes how important humanity is to restore global friendships. Therefore, whenever possible, she always embeds humanity in her lessons. Rachel says that the traditional curriculum allows for other things to be incorporated. She can teach mathematics and science while incorporating other aspects of life as well. Tina thinks embedding humanity in the curriculum is what teachers should be doing every day. Modeling behavior, discussing behavior, and allowing students to learn to express themselves respectfully are all about humanity. Wanda says teachers are responsible for instilling respect for diversity in their students, sparking their awareness of the diverse world. With not all homes teaching children how to be responsible, she sees teaching humanity as teachers' responsibility, such as perseverance, courage, compassion, sportsmanship, peacemaking, and equality. 
Table 4. A summary of fostering students' humanity in the traditional curriculum

\begin{tabular}{lll}
\hline & $\begin{array}{l}\text { Requiring Outside Support } \\
\text { (e.g., Time and Materials) }\end{array}$ & $\begin{array}{l}\text { Decided by } \\
\text { Teacher's Willingness }\end{array}$ \\
\hline Beth & $*$ & $*$ \\
\hline Bianca & $*$ & $*$ \\
\hline Erin & & $*$ \\
\hline Grace & $*$ & $*$ \\
\hline Katniss & & $*$ \\
\hline Kelsie & & $*$ \\
\hline Patrice & $*$ \\
\hline Rachel & & $*$ \\
\hline Wina & & \\
\hline
\end{tabular}

Although all participants believe that it is possible to foster students' humanity in the traditional curriculum, Table 4 above shows that three teachers mention that teachers need outside supports like extra time and materials to make it happen. Most teachers believe that teachers' willingness to teach humanity plays a significant role.

\section{What Participants Like Most About Our Lesson Design}

Beth likes the stories tied with each specific learning goal. She also appreciates that the lessons implement project-based learning and that each lesson has multiple ways for students to access information. Bianca says that her favorite part of the lesson plans is the big ideas: hope, happiness, friendship, sportsmanship, the power of the heart, and courage. All of them are related to students' social-emotional learning, well-being, and mental health. She believes that the lessons will help students understand abstract concepts easily through reading, listening, and discussing the videos. Erin likes our lessons that have real-life connections and use short stories to teach these connections to children. For example, one of the lessons connects to real-life by asking students to work in groups and discuss how to encourage people they cannot see due to the pandemic, making learning accessible and meaningful for students. Grace enjoys that the lessons are engaging, and students will collaborate with one another. Katniss likes how themes are broken down throughout the six lessons and the videos that go with each. The videos allow students to visualize the concepts, and the activities create opportunities for students to collaborate. She also likes that each section of the lesson is given a time frame, and the links to the videos are provided. Kelsie appreciates that the common core state standards are included with the big idea for each lesson plan focusing on humanity. She likes that videos are previously chosen for each lesson, and the corresponding activities are simple and easy for teachers to follow and implement. Patrice expresses that she enjoys reviewing these lessons. She says, "it is a great privilege to view the eight wonderful and value-committed videos of Daisaku Ikeda's children's stories. I truly enjoyed my hours of watching them. I honestly can say I am inspired with renewed convictions after I viewed all the videos." She believes that the differentiated and active learning activities will engage students in fostering their humanity at a deeper level. She states that the various strategies used in the six lesson plans have a huge chance to foster greater knowledge, affection, and psychomotor of the K-12 students. Rachel likes the implementation of ELA standards into the lessons. She also likes that the lessons incorporate collaboration with other students along with independent work. She plans to incorporate the lessons in her classroom. She especially likes the breakdown of project-based learning, which helps students stay focused and does not overwhelm students with the idea of a "project." Tina likes that our lesson plans blend ELA standards with life lessons. Wanda enjoys reading the "hooks" in the lesson plans and how clear the plans are to follow so others can utilize the lessons in their classroom. 
Table 5. A summary of what participants like most about our lesson design

\begin{tabular}{|c|c|c|c|c|c|c|c|c|c|c|}
\hline & Videos & $\begin{array}{l}\text { Themes, } \\
\text { Big } \\
\text { Ideas }\end{array}$ & $\begin{array}{l}\text { Specific } \\
\text { Learning } \\
\text { Goals }\end{array}$ & $\begin{array}{l}\text { Common } \\
\text { Core } \\
\text { Standards }\end{array}$ & $\begin{array}{l}\text { Multiple } \\
\text { Ways of } \\
\text { Learning }\end{array}$ & $\begin{array}{l}\text { Activities } \\
\text { Related to } \\
\text { Real Life }\end{array}$ & $\begin{array}{l}\text { Project- } \\
\text { based } \\
\text { Learning }\end{array}$ & $\begin{array}{l}\text { Peer } \\
\text { Collaboration }\end{array}$ & $\begin{array}{l}\text { Time } \\
\text { Frame } \\
\& \\
\text { Links }\end{array}$ & $\begin{array}{l}\text { Social \& } \\
\text { Emotional } \\
\text { Learning }\end{array}$ \\
\hline Beth & & & $*$ & & $*$ & & $*$ & & & \\
\hline Bianca & & $*$ & & & $*$ & & & & & $*$ \\
\hline Erin & & & & & & $*$ & & & & \\
\hline Grace & & & & & & & & $*$ & & \\
\hline Katniss & $*$ & $*$ & & & & & & $*$ & $*$ & \\
\hline Kelsie & $*$ & $*$ & & $*$ & $*$ & & & & & \\
\hline Patrice & $*$ & & & & $*$ & $*$ & & & & \\
\hline Rachel & & & & $*$ & $*$ & & $*$ & $*$ & & $*$ \\
\hline Tina & & & & $*$ & & & & & & \\
\hline Wanda & & $*$ & $*$ & & & & & & & \\
\hline
\end{tabular}

Table 5 above indicates that teachers appreciate humanity lessons that include engaging videos, themes, specific learning goals, common core standards, multiple ways of learning, activities related to real life, project-based learning, peer collaboration, time frames, video links, and social-emotional learning.

\section{Participants Fear or Concern about Using the Lessons}

Beth states that some teachers may have concerns about teaching broad concepts like hope, courage, etc., especially those who do not focus their teaching on the whole child. Some teachers can feel uncomfortable relaying humanitarian content in veering away from content areas. Bianca says that the biggest concern for teachers would be the amount of time it might take to implement the lessons. She thinks that teachers may need to explain some concepts and give examples to prepare students for class discussions. She suggests that teachers work together, and each grade level comes up with a day once a month to learn about the lesson. Erin believes that the only concern might be teachers' resistance to change. Grace tells us that her concern is to multiple standards simultaneously. She suggests staying with the central message for one week, focusing on one standard each time, and then gradually adding supporting details to the central message and covering other standards. Katniss says that her concern would be the time. Teachers are already required to teach a curriculum set, and the school must approve their instructional activities. She also mentions that not all students will grasp humanity ideas because they have not been taught in the traditional curriculum, which may require teachers to take more time to explain the concepts. Kelsie states that she cannot think of why teachers would not want to use these lessons and modify them to meet the classroom's needs and cultivate students' humanity. Patrice is confident that teachers who know their classes well would not fear or have concerns about incorporating these lessons. She says that fostering students' humanity is not separated from education. It is all teachers do about education. Rachel says that teachers may be concerned with being inexperienced and not having the time to implement the lessons. Tina expresses that teachers may be afraid of trying something new, and thus they might be hesitant to try it. They might also be concerned that the humanity lessons take over the ELA contents. Wanda says teachers might be intimidated to try new lessons since they are often rooted in structure and routines. However, with the lessons being easy to understand and providing necessary tools, links to videos, questions for discussions, and active learning activities, teachers are likely to use them.

Table 6. A summary of fear or concern about using the lessons

\begin{tabular}{|c|c|c|c|c|c|c|c|}
\hline & $\begin{array}{l}\text { Teachers' } \\
\text { Resistance } \\
\text { to Change } \\
\end{array}$ & $\begin{array}{l}\text { Teachers' } \\
\text { Knowledge of } \\
\text { Their Students }\end{array}$ & $\begin{array}{l}\text { Lack of Confidence } \\
\text { in } \\
\text { Humanity }\end{array}$ & $\begin{array}{l}\text { Time } \\
\text { Constraint }\end{array}$ & $\begin{array}{l}\text { Teaching Multiple } \\
\text { Standards at a Time }\end{array}$ & $\begin{array}{l}\text { Students' } \\
\text { Receptive } \\
\text { Ability } \\
\end{array}$ & $\begin{array}{l}\text { Humanity } \\
\text { Content Takes } \\
\text { Over Standards } \\
\end{array}$ \\
\hline Beth & $*$ & & & & & & \\
\hline Bianca & & & & $*$ & & & \\
\hline Erin & * & & & & & & \\
\hline Grace & & & & & $*$ & & \\
\hline Katniss & & & & $*$ & & $*$ & \\
\hline Kelsie & $*$ & & & & & & \\
\hline Patrice & & $*$ & & & & & \\
\hline Rachel & & & $*$ & * & & & \\
\hline Tina & $*$ & & & & & & $*$ \\
\hline Wanda & * & & $*$ & & & & \\
\hline
\end{tabular}


Table 6 above illustrates that teachers, in general, may have fear or concerns about using the lessons due to resistance to change, knowledge of their students, lack of confidence in teaching humanity, time constraint, multiple curriculum standards, students' receptive ability, and humanitarian contents.

\section{Participants' Suggestions for Using the Lessons}

Beth suggests adding assessment criteria to each lesson. In this way, it will help teachers modify lessons for their students. Bianca recommends using graphic organizers in the lesson to help students recall details of the stories in a whole class or small groups. She also says being specific about what type of concept maps would clarify what students need to do, such as comparing and contrasting the stories and leading students to discuss characters across stories. Erin thinks it would be great to include accommodations for students with disabilities and English language learners. Grace suggests teachers modify the stories and allow students to see characters in the stories that look like them, such as having charters from the same culture, speaking the same language, having similar family lives, etc. She believes that stories with these characters resonate better with students and allow for a more in-depth conversation while visually seeing and imagining how to be good citizens in society. Katniss suggests considering students' different abilities. Some students may grasp the concepts quickly, but some may not. She suggests that having extension and remediation tasks available for each lesson will be helpful. Adding individualized assessment rubrics will also make the lessons user-friendly to teachers. Furthermore, she suggests adding graphic organizer activities and an introductory lesson on humanity will make the lessons more effective. Kelsie suggests adding differentiation for students with special needs, including both instruction and assessment. Patrice would like to see assessment rubrics for assessing students' learning performance, helping teachers set clear expectations, and enhancing their implementation of the lessons. Rachel suggests giving more specific standards to make implementation easier for teachers. She points out that Lesson 3 could be easily adapted to teach life science in $7^{\text {th }}$ grade, earth science in $6^{\text {th }}$ grade, and the lessons could be adapted for physical education classes. Another thing she suggests is developing project-based learning rubrics. Tina believes that breaking down the lessons into smaller components or designing the lesson plans over a grading period. Wanda does not see anything missing from the lessons. She says all lessons are feasible for teachers to adapt for their students.

Table 7. A summary of participants' suggestions for using the lessons

\begin{tabular}{|c|c|c|c|c|c|c|c|c|}
\hline & $\begin{array}{l}\text { Adding } \\
\text { Rubrics for } \\
\text { Assessments } \\
\text { \& Behavior }\end{array}$ & $\begin{array}{l}\text { Adding } \\
\text { Graphic } \\
\text { Organizers } \\
\text { Activities }\end{array}$ & $\begin{array}{l}\text { Adding } \\
\text { Accommodations } \\
\text { for Students with } \\
\text { Special Needs }\end{array}$ & $\begin{array}{l}\text { Modifying } \\
\text { Stories for } \\
\text { Targeted } \\
\text { Students }\end{array}$ & $\begin{array}{l}\text { Adapting } \\
\text { the } \\
\text { Lessons } \\
\text { for Other } \\
\text { Subject } \\
\text { Matters }\end{array}$ & $\begin{array}{l}\text { Adding an } \\
\text { Introductory } \\
\text { Lesson about } \\
\text { Humanity }\end{array}$ & $\begin{array}{l}\text { Breaking } \\
\text { Down Each } \\
\text { Lesson into } \\
\text { Smaller } \\
\text { Components }\end{array}$ & $\begin{array}{l}\text { No } \\
\text { Suggestion }\end{array}$ \\
\hline Beth & $*$ & & & & & & & \\
\hline Bianca & & $*$ & & & & & & \\
\hline Erin & & & $*$ & & & & & \\
\hline Grace & & & & $*$ & & & & \\
\hline Katniss & $*$ & $*$ & $*$ & & & $*$ & & \\
\hline Kelsie & & & $*$ & & & & & \\
\hline Patrice & $*$ & & & & & & & \\
\hline Rachel & $*$ & & & & $*$ & & & \\
\hline Tina & & & & & & & $*$ & \\
\hline Wanda & & & & & & & & $*$ \\
\hline
\end{tabular}

Table 7 above summarizes participants' suggestions for using these lessons in the classroom, including adding assessment rubrics, graphic organizer activities, accommodations for diverse learning, story modification, adaptions for other subject matters, an introductory lesson on humanity, and breaking down each lesson into smaller components.

\section{Significance of the Study}

Ikeda's humanitarian work is recognized globally and impacts education profoundly. Our synthesis of the book, Hope and Joy in Education, indicates that creating hope and joy in education is inseparable from human revolution, value creation, happiness, the greater self, global citizens, as well as life and 
death. Addressing these issues gives students the courage to continue advancing no matter what the circumstances are. Students are hungry to be happy, but education with a strong focus on preparing students for standardized tests is far from filling students' hearts with courage. To live a life of hope and joy, students should not be absorbed with just their own betterment but knowing how lives are all inextricably linked. When teachers are willing to embed humanity in the curriculum and engage in earnest dialogue with students, they can bring forth students' inherent wisdom and revitalize their humanity at a deeper level.

So how to actualize hope and joy in education? Although teachers generally value humanity, lacking experience in incorporating humanity in the curriculum makes teachers wonder how to engage students in learning about humanity. Based on the six themes identified in the articles by scholars involved in Ikeda studies, we reviewed Ikeda's children's stories and developed lesson plans as concrete examples for teachers in K-12 curricula. By no means would we consider these lessons exemplary or applicable in all different contexts. Instead, we consider these lessons a starting point to continue exploring a better way to teach humanity in school. Some teachers have a strong desire to teach humanity with existing materials, and others have wonderful creativity to modify materials for their unique teaching context. It is of course up to teachers' preferences and experiences to decide how to use these free materials. For that reason, there is no need for teachers to use these lessons in the same way. Instead of merely using the lessons, we encourage teachers to ask themselves why to teach humanity and how to teach it. We hope that these lessons with various instructional activities could give teachers some ideas to start with or provoke their thinking about humanity in the curriculum. And most importantly, at the root of everything about education, we hope to help students lead fulfilled and happy lives.

The participant's responses to the six survey questions help educators and researchers see what K-12 teachers look for in order to implement lessons on humanity more efficiently and effectively. For example, participants noted that the lessons lesson plans, including active learning activities, guidance for educators, and common core standards, increase the possibilities to be used in the classroom. Assessment rubrics and accommodations for diverse learners will also be helpful to teachers.

\section{Conclusion}

In a nutshell, the synthesis of scholars' work in Ikeda studies and teacher surveys indicate that it is vital to cultivate youths' humanity, leading them to create happiness for themselves and others. Seeing examples of lesson plans on humanity and learning from K-12 teachers' perspectives provide an aspect for educators and researchers to use, extend, or expand the present study to bring hope and joy to students in their local contexts. Instead of counting all the things teachers cannot do to embed humanity in K-12 curricula, we help teachers understand what they can do to bring hope and joy to education. Valuing humanity in the curriculum is one of the qualities that make education worthy. Because of this, teachers have a responsibility to cultivate the humanity of each student, polishing their lives through facing difficulties with hope and joy.

\section{References}

Berry, T.R. (2021). Finding hope and joy in curriculum theory through critical race feminism. In I. Nunez \& J. Goulah (Eds.), Hope and joy in education: Engaging Daisaku Ikeda across curriculum and context (pp. 80-91). Teachers College Press.

Bogen, M. (2021). Hope, joy, and the greater self at the Ikeda Center for Peace, Learning, and Dialogue. In I. Nunez \& J. Goulah (Eds.), Hope and joy in education: Engaging Daisaku Ikeda across curriculum and context (pp. 145-156). Teachers College Press.

Bradford, M. R. (2018). Friends in the orchid room: An inquiry into value-creative dialogue (Unpublished doctoral dissertation). DePaul University, Chicago, IL.

Bradford, M. R. (2021). Imparting hope and inspiring joy: Practicing value-creative dialogue in educational leadership. In I. Nunez \& J. Goulah (Eds.), Hope and joy in education: Engaging Daisaku Ikeda across curriculum and context (pp. 54-65). Teachers College Press. 
Childre, A., Sands, J. R., \& Pope, S. T. (2009). Backward design. Teaching Exceptional Children, 41(5), 6-14.

Donahue-Keegan, D. (2021). Social-emotional learning and value-creating education: Synergistic possibilities of cultivating hope and joy in higher education. In I. Nunez \& J. Goulah (Eds.), Hope and joy in education: Engaging Daisaku Ikeda across curriculum and context (pp. 104112). Teachers College Press.

Garrison, J., Hickman, L. \& Ikeda, D. (2014). Living as learning: John Dewey in the 21st century. Dialogue Path Press.

Goulah, J. (2021). Introduction: Daisaku Ikeda, and hope and joy in education. In I. Nunez \& J. Goulah (Eds.), Hope and joy in education: Engaging Daisaku Ikeda across curriculum and context (xiii-xxxiv). Teachers College Press.

Hall, C., Krueger-Henney, P., Kunimoto, N. M., \& Zakharia, Z. (2021). "Hope is a decision": Pedagogical acts toward the collective commitment to remake the world. In I. Nunez \& J. Goulah (Eds.), Hope and joy in education: Engaging Daisaku Ikeda across curriculum and context (pp. 21-33). Teachers College Press.

Huckaby, M. F. (2021). A fundamental force at the edges of the formation of society. In I. Nunez \& J. Goulah (Eds.), Hope and joy in education: Engaging Daisaku Ikeda across curriculum and context (pp. 34-44). Teachers College Press.

Ikeda, D. (2002). The wisdom of the Lotus Sutra (Volume IV). World Tribune Press.

Ikeda, D. (2009). The flowering of the greater self: Message to the Ikeda Center on the occasion of the publication of Creating Waldens. Retrieved from http://www.ikedacenter.org/20thanniversary/ikeda-messages

Ikeda, D. (1997). Learning from the Gosho, happiness in this world. Living Buddhism, 1(12), 7-15.

Ikeda, D. (2009). The flowering of the greater self. Retrieved from https://www.ikedacenter.org/20thanniversary/ikeda-messages/2009

Ikeda, D. (2010a). A New Humanism. I.B. Tauris.

Ikeda, D. (2010b). Soka education: For the happiness of the individuals. Middleway Press.

Ikeda, D. (2014). Value creation for global change: Building resilient and sustainable societies. Retrieved from https://www.daisakuikeda.org/assets/files/peaceproposal2014.pdf

Ikeda, D. (2017). Hope is a decision. Middleway Press.

Ikeda, D. (2018). Foreword. In P. Stearns (Ed.), Peacebuilding through dialogue: Education, human transformation, and conflict resolution (pp. vii-xi). George Mason University Press.

Ikeda, D. (2021). Value creation in a time of crisis. 2021 peace proposal to the United Nations (Synopsis). Retrieved from https://www.daisakuikeda.org/sub/resources/works/props/2021peace-proposal.html

Ikeda, D. (n.d). On writing children's stories. Retrieved from https://www.daisakuikeda.org/main/culture/essays-on-culture/kwong-wah-daily-malaysiachildrens-stories.html

Inukai, N. \& Okaura, M. (2021). Determining to be hopeful in hopeless times. In I. Nunez \& J. Goulah (Eds.), Hope and joy in education: Engaging Daisaku Ikeda across curriculum and context (pp. 10-20). Teachers College Press.

Kuckartz, U. (2013). Three basic methods of qualitative text analysis. SAGE Publications.

Kuo, N. C. (2020). Daisaku Ikeda's philosophical dialogues on education. FIRE: Forum for International Research in Education, 6(2), 89-102.

Lifshitz, A. (1997). The human, humanistic, humanist, and humanitarian in medicine. Gac Med Mex, 133(3), 237-243.

Lupinacci, J. (2021). Value creation and the revitalization of dependency as a core goal of ecocritical education. In I. Nunez \& J. Goulah (Eds.), Hope and joy in education: Engaging Daisaku Ikeda across curriculum and context (pp. 157-167). Teachers College Press.

Mattheis, A. (2021). Building a change-focused community with practitioners as a source of hope. In I. Nunez \& J. Goulah (Eds.), Hope and joy in education: Engaging Daisaku Ikeda across curriculum and context (pp. 45-53). Teachers College Press.

Nunez, I. \& Goulah, J. (2021). Hope and joy in education: Engaging Daisaku Ikeda across curriculum and context. Teachers College Press. 
Patterson, A. (2021). Restoring hope for the humanities: Daisaku Ikeda, intercultural study, and college classroom experience. In I. Nunez \& J. Goulah (Eds.), Hope and joy in education: Engaging Daisaku Ikeda across curriculum and context (pp. 69-78). Teachers College Press.

SGI Quarterly (2015). Life and death. Retrieved from https://www.sokaglobal.org/resources/studymaterials/buddhist-concepts/life-and-death.html

The Gosho Translation Committee (2006). The Writings of Nichiren Daishonin, Vol. 2, p. 759. Tokyo: Soka Gakkai.

Wiggins, G., \& McTighe, J. (1998). Understanding by design. Association for Supervision \& Curriculum Development.

World Tribune (2001, October 12). Fostering global citizens. p. 7. 